\title{
Pembelajaran Online dengan Aplikasi Zoom Meeting di Kelas 5 SDN 1 Selaawi di Masa Pandemi Covid-19
}

\author{
Ahmad Solihin \\ Magister Teknologi Pendidikan, Institut Pendidikan Indonesia, Garut, Indonesia \\ E-mail: ahmadsolihin1980@yahoo.com/ahmadsolihin0007@gmail.com
}

\begin{abstract}
Abstrak
Tahun 2020 merupakan tahun dimana penyebaran Covid-19 yang semakin tidak terkendali hampir di seluruh Negara di dunia dan tidak terkecuali negara kita Indonesia marasakan dampaknya. kebekuan terjadi pada berbagai sektor tak terkecuali sektor pendidikan yang sama sekali tidak bisa melaksanakan tatap muka pembelajaran, menanggapi keadaan ini pemerintah mengeluarkan kebijakan seluruh sekolah tidak boleh melaksanakan pembelajaran di kelas dan bertatap muka secara langsung. Kebijakan Pembelajaran Jarak Jauh (PJJ) dengan program bantuan kuota belajar yang dikeluarkan pemerintah sebagai solusi agar sector pendidikan tetap berjalan kreatifitas guru dituntut untuk bisa menggunakan berbagai platform aplikasi pembelajaran online yang tersedia sangat banyak namun kemanfaatan dan efektifitasnya sangat berbeda. Salah satu upaya untuk menyikapi kebijakan pemerintah, kelas 5 SDN 1 Selaawi Garut mengambil langkah pembelajaran dengan memanfaatkan fasilitas Aplikasi Zoom Meeting yang bisa diakses melalui kuota belajar sebagai alternatif strategis yang sangat efektif bagi keberlangsungan proses belajar di tengah pandemi. Dengan metode pengkajian kualitatif dapat dijadikan rujukan untuk mengetahui proses pembelajaran guru dan respon siswa di kelas 5 SDN 1 Selaawi dalam pembelajaran online yang baik dengan aplikasi Zoom Meeting .
\end{abstract}

Kata kunci: Aplikasi Zoom Meeting; Pembelajaran Online; Pembelajaran jarak jauh

\section{PENDAHULUAN}

Kesulitan guru dalam melaksanakan pembelajaran berdasarkan kebijakan yang ditetapkan oleh pemerintah di tengah mewabahnya corona virus desease 19 yang mengharuskan warganya untuk tetap stay at home, bekerja, beribadah dan belajar di rumah (Ratu et al., 2020). Kondisi tersebut sangat menyita perhatian dan menimbulkan kebingungan terutama dalam pembelajaran secara online yang benar-benar minim fasilitas, kemampuan guru dalam penggunaan berbagai platform aplikasi pembelajaran online terbantahkan dengan adanya keterbatasan fasilitas dan kemampuan siswa dalam pembelajaran online, keadaan tersebut hampir dapat mematikan interaksi antara pengajar dengan pelajar dan memutuskan kegiatan pembelajaran yang seyogyanya bisa dilaksanakan, berdasarkan hal tersebut dibutuhkan need analysis terhadap keadaan yang sedang berlangsung dimana guru harus bisa memberikan pembelajaran dengan benar dan siswa tidak terlalu kesulitan dalam melaksanakan pembelajaran. Solusi tersebut menjadi bahan kajian yang sangat diperlukan untuk menjembatani keberlangsungan pembelajaran yang bisa diakses oleh semua dengan segala keterbatasan namun bisa berlangsung dengan efektif.

Dunia pendidikan memiliki taruhan jangka panjang, yang akan berpengaruh terhadap kelangsungan sumberdaya manusia dan masa depan Indonesia sendiri. Jika tanpa pencermatan dan kesungguhan rencana yang tepat atas dampak covid-19, maka berkemungkinan besar generasi terdidik bangsa ini menjadi korban dan klaster penularan covid-19 yang sangat masif. Dalam posisi ini, loss 
gennerasation secara fisik terhadap sumber daya manusia mendatang menjadi kenyataan pahit bagi bangsa ini. Oleh karenanya, kita patut untuk melihat akan dinamika pelaksanaan kebijakan new normal dan dampaknya terhadap kelangsungan pendidikan (Heri Dwiyanto, 2020).

Tidak adanya kepastian di saat pandemi covid-19 melanda Indonesia, membuat dunia pendidikan khususnya sekolah juga harus melakukan reorientasi dalam banyak hal, khususnya penyelenggaraan kurikulum di satuan pendidikan. Meskipun dibuat skema protokoler agar bidang pendidikan tetap berlangsung nanti di masa new normal, namun rencana penyelenggaraan proses pembelajaran secara langsung berbasis Luring menuai banyak kritikan dan juga penuh kekhawatiran.

Pembelajaran Jarak Jauh secara Online dengan menggunakan berbagai platform aplikasi (Darmawan, 2012) dipandang tepat dalam situasi tersebut, walaupun dalam pelaksanaannya tidak terlepas dari berbagai kendala teknis yang terjadi, terbatasnya akses internet di seluruh negeri, terbatasnya perangkat yang memadai pada seluruh siswa, kost quota yang sangat mahal dan berbagai permasalahan lainya mewarnai keaadaan pembelajaran PJJ ditengan pandemi ini di SDN 1 Selaawi. Sebagian besar proses PJJ saat ini masih memanfaatkan fasilitas grup Whatsapp dalam perangkat Smartphone. Guru memberikan tugas kepada para peserta didik melalui grup Whatsapp, baik melalui grup orang tua siswa maupun grup kelas masing-masing. Waktu belajar sesuai dengan jadwal mata pelajaran harian. Materi belajar dipelajari secara mandiri kemudian dilanjutkan dengan mengerjakan tugas harian. Bertumpuknya tugas yang diberikan guru menimbulkan masalah baru bagi orang tua siswa yang harus melihat keluh kesah anaknya dengan pembelajaran.

Di masa New Normal ini, kita masih tetap di anjurkan untuk selalu menerapkan Social Distancing, Physical Distancing (NurCita \& Susantiningsih, 2020), dan mentaati protokol kesehatan. Zoom Meeting hadir menjawab semua permasalahan ini. Pendidik (guru) tetap bisa melaksanakan pembelajaran dengan nyaman dan menyenangkan secara live bersama dengan peserta didiknya. Pembelajaran yang dilakukan siswa tidak membosankan karena guru bisa memberikan pembelajaran dan siswa bisa berkomunikasi langsung untuk menanyakan berbagai permasalahan dalam materi pembelajaran secara interaktif dengan guru. Hadirnya kebijakan pemerintah mengenai bantuan kuota belajar (Salinan PERSESJEN Nomor 14 Tahun 2020, 2020) menjadi faktor pendukung keterbatasan kost pemakaian kuota yang bisa digunakan untuk berbagai aplikasi edukasi. Oleh karena itu pemanfaatan Aplikasi Zoom Meeting sebagai aplikasi edukasi (CNN Indonesia, 2020) menjadi salah satu alternative dalam pembelajaran di kelas 5 SDN 1 Selaawi .

\section{METODE}

Metode dalam kajian ini merupakan metode riset kualitatif (Darmawan, 2013) dengan study kasus yang fokus terhadap pelaksanaan pembelajaran menggunakan Aplikasi Zoom Meeting di SDN 1 selaawi dengan observasi dokumentasi dalam pegumpulan data.

Teknik pengumpulan data dalam penelitian ini menggunakan angket yang dimodifikasi dan disesuaikan dengan keadaan WFH yaitu berupa angket elektronik dengan menggunakan aplikasi 
Gunahumas

Jurnal Kehumasan

Google Formulir yang diberikan kepada siswa.

Sasaran dari penelitian ini adalah 20 Siswa kelas 5 SDN 1 Selaawi tahun pelajaran 2020-2021. Dengan lokasi penelitian terfokus di rumah dan lingkungan SDN 1 Selaawi Kecamatan Selaawi Kabupaten Garut, Jawa Barat, Indonesia.

\section{HASIL DAN PEMBAHASAN}

\section{Pola Pembelajaran PJJ}

Keberlakuan masa New Normal ditengah pandemic covid-19 ini khususnya bagi dunia pendidikan di Indonesia, guru-guru dituntut dapat memberikan pembelajaran yang kreatif sehingga mampu memaksimalkan potensi yang dimiliki siswa. Guru sebagai fasilitator diharapkan mampu menganalisis kebutuhan siswanya dan memfasilitasi pembelajaran online (Adam, 2015) yang sesuai dengan keadaan dan karakter siswa.

\section{Pembelajaran menggunakan Aplikasi} Zoom Meeting

Pembelajaran dengan menggunakan Aplikasi Zoom Meeting merupakan pembelajaran dengan menggunakan media audio visual secara online (daring). Sehingga dengan media audio visual secara online (Yusantika \& Suyitno, 2018) merupakan metode yang mengajarkan bahasa dengan memanfaatkan alat pandang dengar seperti video, kartu, tape recorder, atau program televisi sehingga pengajaran menjadi lebih hidup dan menarik (Iskandarwassid dan Sunendar, 2011), Sedangkan menurut (Muthoharoh, 2010) metode audio visual menyajikan bahan pelajaran dengan menggunakan media pengajaran yang dapat memperdengarkan atau memperagakan bahan-bahan tersebut
p-ISSN: 2338-1507

Vol 3, No 2, 2020, 17-24

sehingga siswa dapat menyaksikan, mengamati, memegang atau merasakan secara langsung.

Aplikasi Zoom Meeting memiliki fungsi untuk komunikasi dengan menggunakan video dan audio melalui jaringan internet. Aplikasi ini sangat berguna untuk proses belajar mengajar secara online serta rapat - rapat penting perusahaan tanpa perlu kita bertatap muka langsung. Zoom Meeting merupakan sebuah aplikasi video conference yang dikembangkan oleh perusahaan asal Amerika Serikat (Archibald et al., 2019).

Zoom adalah layanan konferensi video kolaboratif berbasis cloud yang menawarkan fitur termasuk rapat online, layanan perpesanan grup, dan perekaman sesi yang aman (Inc, 2016) yang dapat digunakan pada perangkat komputer, smartphone sampai sistem ruang. Aplikasi Zoom Meeting ini tersedia dalam empat pilihan ( Basic / Gratis, Pro, Business dan Enterprices ), Beberapa fitur yang ditawarkan oleh aplikasi Zoom Meeting ini antara lain sebagai berikut :

1. HD Video dan Audio

Kualitas high definition dengan jumlah peserta hingga 1000 orang dalam grid layar.

2. Keamanan

Keamanan dengan teknologi end-to-end encryotion, selain itu aplikasi ini juga dilengkapi dengan fitur keamanan sandi untuk setiap penggunanya.

3. Rekaman dan Transkrip

Fitur recording, sehingga kegiatan rapat dapat terdokumentasi dan dapat dibuka kembali sewaktu - waktu.

4. Berbagi Layar

Fitur berbagi layar, sehingga para peserta rapat dapat berintmasaksi dengan lebih intmasaktif.

5. Penjadwalan 
Fitur penjadwalan yang dapat diinformasikan melalui email atau ical.

6. Obrolan Tim

Obrolan group menjadi lebih mudah. Sehingga kita akan merasa lebih dekat dengan anggota rapat yang lainnya.

7. Riwayat

Dilengkapi dengan history obrolan dan akan tersimpan dalam arsip sistem hingga sepuluh tahun.

Adapun Langkah Penggunaan Aplikasi Zoom Meeting dalam Pembelajaran (Kamil, n.d.) adalah :

1. Download Aplikasi Zoom

Sebelum masuk lebih lanjut tentang cara penggunaan aplikasi Zoom, silahkan terlebih dahulu Download Aplikasi Zoom, bisa mendowloadnya melalui situs resmi zoom.us atau bisa melalui link ini. Bagi pengguna Android, bisa kamu download melalui aplikasi Google Playstore.

2. Registrasi atau Membuat Akun di Zoom Meeting

Setelah kamu download, lakukan instalasi seperti biasanya. Kemudian setelah selesai akan masuk pada tampilan awal aplikasi Zoom.

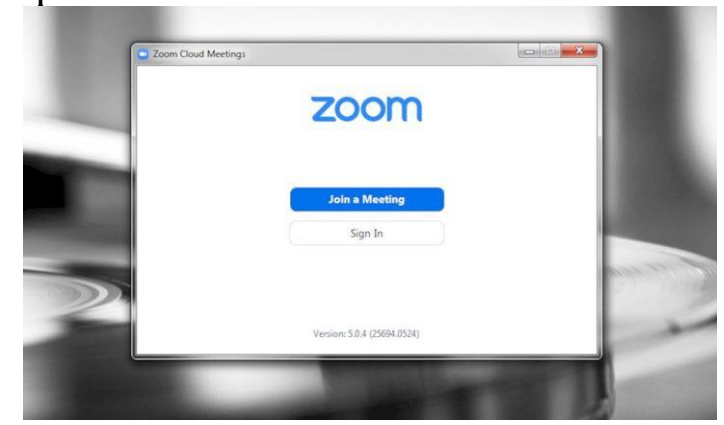

Lakukan Sign In agar dapat melakukan pembelajaran dengan peserta didik. Masukkan akun Zoom.

3. Buat Schedule (Jadwal) pembelajaran

Setelah melakukan Sign In, maka akan masuk pada tampilan awal Zoom, kemudian klik menu Schedule

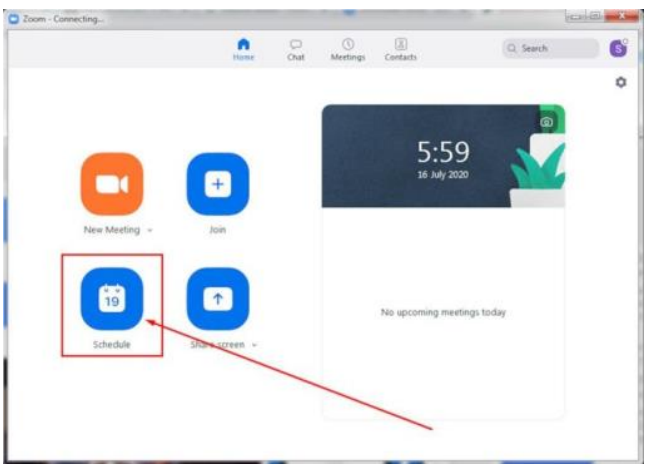

4. Membuat Schedule Di Zoom

Silahkan isi poin-poin penting pada menu Schedule ini.

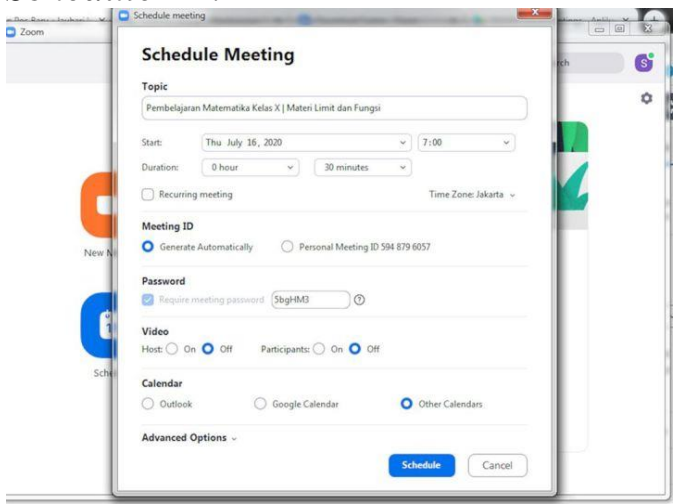

5. Mengisi Schedule Di Zoom

a. Topic : Silahkan isi dengan materi pembelajaran yang akan di sampaikan kepada siswa. Misalnya Pembelajaran Tema 1 Subtema 2 Pembelajaran 3

- Start : Kapan pembelajaran akan dilaksanakan, isikan tanggal dan jam

- Duration: Maksimal pembelajaran akan dilaksanakan. Untuk akun Basic, zoom memberikan waktu maksimal 40 Menit saja.

\section{b. Meeting ID}

Pada Meeting ID terdapat dua pilihan, silahkan kamu pilih yang mana saja sesuai dengan keinginan. Hanya saja pada Personal Meeting merupakan ID yang tidak akan pernah berubah.

c. Password

Silahkan isi password pembelajaran. Agar yang bukan peserta didik atau 
Gunahumas

Jurnal Kehumasan
p-ISSN: 2338-1507

Vol 3, No 2, 2020, 17-24 peserta kelas tidak bisa masuk pada kelas pembelajaran kita.

d. Video

Karena ini sifatnya tatap muka, jadi Video harus di ON semua. Host merupakan Video guru sebagai Pendidik, dan Paticipants adalah peserta didik (siswa).

e. Calendar

Silahkan pilih saja Other Calendar agar kamu tidak perlu membuat akun lagi untuk calendar tersebut. Pada bagian ini hanya akan menampilkan teks yang berupa undangan yang dapat dikirimkan kepada peserta didik. Kemudian klik Schedule.

6. Mengirimkan ID dan Password Pembelajaran kepada Siswa

Maka akan menghasilkan tampilan seperti ini. Silahkan klik Copy to Clipboard, kemudian paste pada pada WhatsApp, Gmail atau Group Kelas untuk mengirimkan undangan pembelajaran ini.

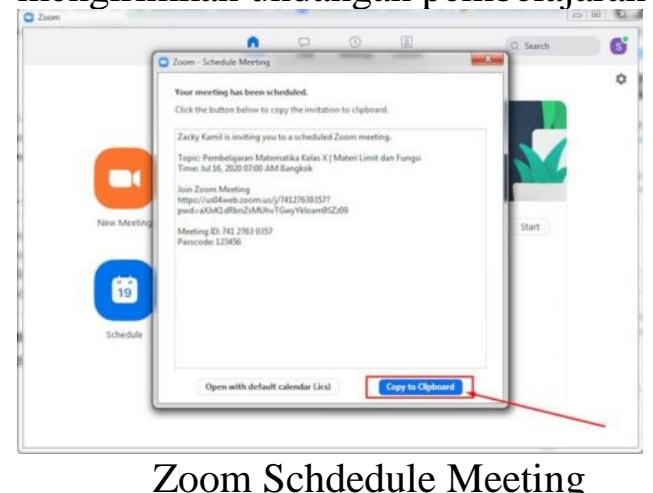

Hasil

Tabel Analisis Uraian

\begin{tabular}{lll}
\hline No & Variabel & Presentase \\
\hline I & $\begin{array}{l}\text { Mendukung pelaksanaan } \\
\text { pembelajaran melalui } \\
\text { aplikasi Zoom Meeting }\end{array}$ & $85 \%$
\end{tabular}

II

Semakin naik semangat belajar

$95 \%$

Sumber:

Pada hasil analisis disebutkan bahwa siswa yang mendukung pelaksanaan pembelajaran melalui aplikasi Zoom Meeting ada 90\%, sedangkan $10 \%$ lainnya tidak mendukung pelaksanaan pembelajaran melalui aplikasi Zoom Meeting karena tidak mempunyai perangkat HP android.

Hasil dari hasil analisis diatas menunjukan bahwa proses pembelajaran menggunakan aplikasi Zoom Meeting di SDN 1 Selaawi berlangsung dengan sangat baik. Siswa terlihat semangat dengan pembelajaran, respon dan antusias siswa dalam pembelajaran melaui kelas aplikasi Zoom Meeting ini disebabkan siswa merasa masuk dalam media pembelajaran yang baru, kebiasaan mereka memakai fasilitas Handphone hanya untuk sekedar bermain atau searching dan youtube saja sekarang mereka memakainya dalam pembelajaran formal.

Dengan pembelajaran seperti ini siswa seakan-akan tidak merasakan perbedaan antara pembelajaran yang bisa dilaksanakan di kelas pada masa sebelum covid-19 dengan masa WFH sekarang.

\section{SIMPULAN}

Aplikasi Zoom Meeting dengan segala kelebihannya yang bisa digunakan dengan memanfaatkan quota belajar dapat menjadi solusi alternative pembelajaran audio visual yang sangat baik dalam Pembelajaran jarak jauh (PJJ) di masa pandemi Covid-19.

Kelebihan dari aplikasi ini dapat menjadikan pembelajaran online dengan interaksi tatap muka langsung sehingga 
siswa tidak merasakan perbedaan antara pembelajaran di kelas dengan pembelajaran jarak jauh namun dari kelebihannya itu aplikasi Zoom Meeting ini memiliki kekurangan yang hanya bisa diakses dengan kuota yang sangat besar sehingga menjadi kendala apabila program bantuan kuota belajar dari pemerintah tidak berlanjut. Proses pembelajaran menggunakan aplikasi Zoom Meeting di SDN 1 Selaawi mendapatkan hasil yang positive dilihat dari respon dan antusias siswa dalam mengikuti proses pembelajaran, hal tersebut sejalan dengan meningkatnya kemampuan siswa kelas 5 SDN 1 Selaawi dalam memahami materi pembelajaran walaupun dalam kondisi WFH.

Bagi siswa yang memiliki keterbatasan perangkat HP android atau laptop sebaiknya disarankan untuk bisa bergabung dengan siswa lain yang berdekatan sehingga pembelajaran bisa berlangsung lebih optimal.

\section{DAFTAR PUSTAKA}

Adam, s dan M. T. (2015). Pemanfaatan Media Pembelajaran Berbasis Teknologi Informasi. CBIS Journal, 3(2), 78-90.

Archibald, M. M., Ambagtsheer, R. C., Casey, M. G., \& Lawless, M. (2019). Using Zoom Videoconferencing for Qualitative Data Collection: Perceptions and Experiences of Researchers and Participants. International Journal of Qualitative Methods, 18, 1-8. https://doi.org/10.1177/16094069198 74596

CNN Indonesia. (2020). daftar-aplikasisitus-bisa- diakses-kuota-belajar- kemdikbud.

Https://Www.Cnnindonesia.Com/Nas ional/20200921114013-20-548858, 548858.

Darmawan, D. (2012). Pendidikan Teknologi Informasi dan Komunikasi Teori dan Aplikasi. Bandung : PT Remaja Rosdakarya, 2012.

Darmawan, D. (2013). Metode Penelitian Kuantitatif. Bandung: PT Remaja Rosda Karya, 204-207.

Heri Dwiyanto. (2020). Menyiapkan Pembelajaran dalam Memasuki “ New Normal " dengan Blended Learning. Pengembang Teknologi Pembelajaran LPMP Lampung, 2019, 1-9.

Inc, Z. V. C. (2016). Security guide. Zoom Video Communications Inc. Https://D24cgw3uvb9a9h.Cloudfront .Net/Static/81625/Doc/ZoomSecurity-White-Paper.Pdf, 81625.

Iskandarwassid dan Sunendar, D. 2011. (2011). Iskandarwassid dan Sunendar, Dadang. 2011. Strategi Pembelajaran Bahasa. Bandung: PT Remaja Rosda Karya. In Strategi Pembelajaran Bahasa. PT Remaja Rosda Karya.

Kamil, Z. (n.d.). Zack Kamil, https://www.jauhari.net/caramenjadikan-zoom-sebagai-mediapembelajaran-tatap- muka-daring16252. 16252.

Muthoharoh, H. (2010). Metode Audiovisual. In Metode Audiovisua.

NurCita, B., \& Susantiningsih, T. (2020).

Dampak Pembelajaran Jarak Jauh

Dan Physical Distancing Pada

Tingkat Kecemasan Mahasiswa

Fakultas Kedokteran Universitas Pembangunan Nasional "Veteran" Jakarta. Journal of Borneo Holistic Health, 3(1), 58-68.

Ratu, D., Uswatun, A., \& 
Gunahumas

Jurnal Kehumasan

Pramudibyanto, H. (2020).

Pendidikan Dalam Masa Pandemi

Covid-19. Jurnal Sinestesia, 10(1), 41-48.

Salinan PERSESJENNomor 14 Tahun 2020. (2020). Salinan Persesjen

Nomor 14 Tahun 2020.
p-ISSN: 2338-1507

Vol 3, No 2, 2020, 17-24

Yusantika, F. D., \& Suyitno, I. (2018). Pengaruh Media Audio dan Audio Visual terhadap Kemampuan Menyimak Siswa Kelas IV. 2013, 251-258. 